\title{
Verbal Clause Construction of Ciacia Language: Syntactic Typology Study
}

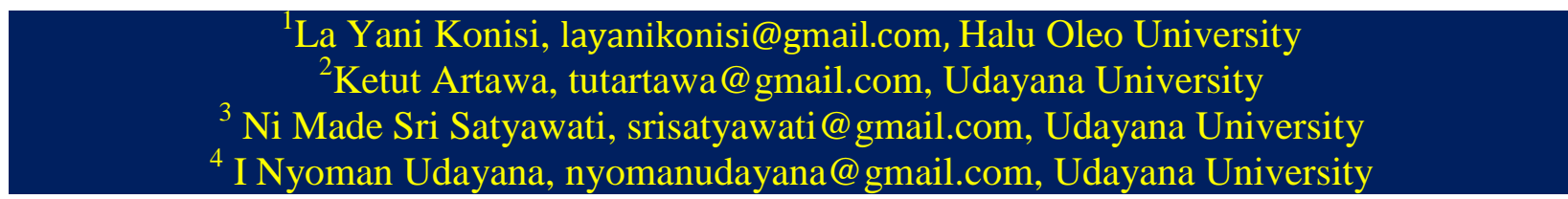

*Corresponding Author: layanikonisi@gmail.com

Received Date: 28-05-2018 Accepted Date: 11-06-2018 Published Date: 04-01-2019

Abstract - Typology study of Ciacia language (CL) in various linguistic aspects has not been conducted yet. It is the first study that focus on syntactic typology. Ciacia language is one of local languages in Buton Regency, Southeast Sulawesi Province. The study focuses on five main problems, they are (1) How is the base construction of verbal clause in CL? (2) How are the predicate and structure argument constructions of verbal clause in CL, (3) How are the simple predicate and complex predicate constructions of verbal clause in CL? (4) How are valency and valency change mechanism of verbal clause construction in CL? (5) How are complex sentence construction and grammatical alliance system?. The oral data of this study is obtained through recording and elicitation techniques. Written data is obtained through the previous studies. The study also used synthetic data which is verrified by the informants. The data was analyzed by apportion (distributional) method.

The investigation of clause base construction shows that verbal clause construction of Ciacia language is always filled by subject and aspect markers (PS/A) that is affixed to PRED verb. Base structure of verbal clause in CL consists of verbal predicated clause and non-verbal predicated clause. Non-verbal predicated clause can be constructed through base nominal and adjective categories. Verbal clause predicate can be filled by intransitive base verb, mono transitive base verb, ditransitive base verb, and ambi-transitive base verb.

Predication and argument structure of verbal clause construction in CL can be classified in to verbal clause: (i) intransitive with one main argument in terms of SUBJ and as A or OBJ systematically; (ii) semi-transitive with one main argument as A/ACT and with the presence of OBJ argument optionally; (iii) mono-transitive with two main arguments, namely SUBJ as A/ACT with one OBJ argument as UND, (iv) ditransitive with three main arguments, namely SUBJ as A/ACT before PRED and two arguments after PRED, in terms of OTL (indirect object) and OL (direct object); and (v) ambi-transitive with one main argument, namely SUBJ, either as Sa or as So.

Valency and transitivity of verbal clause construction in CL consists of (i) valency and intransitive verb transitivity with one argument or verb with one valency; (ii) semi-transitive verb with one argument before verb and the presence of argument after Pred verb optionally; (iii) transitive with the obligatory of $\mathrm{O}$ presence after Pred verb, so it has two main arguments or verb that has two valency arguments, namely $\mathrm{S}$ and $\mathrm{O}$; (iv) ditransitive with three main

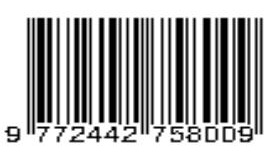


arguments or verb that has three valency arguments; (v) ambi-transitive with only one argument or verb that has one valency.

Verbal clause construction in CL can be filled by simple Pred verb and complex Pred verb. Simple predicate is created by base verb/intransitive verb and non-verb category, semitransitive verb, and transitive verb with PS/A. Complex predicate is created through verb (i) intransitive; (ii) semi-transitive verb; and (iii) transitive integral verb. The valency change mechanism of verbal clause construction in CL can be done through formal causativation and semantic causativation, applicative, and resultative.

\section{Key Words: syntactic typology, valency, nominative-accusative}

\section{Introduction}

Ciacia language (CL) is one of local languages in Buton Regency, Southeast Sulawesi. Besides, there are other local languages in Buton, such as Wolio language (a language in Buton Sultanate Palace) which is used in Kapuntori and Lasalimu Districts, Tukang Besi language (it is called as Wakatobi or Pulo language) which is spoken in Pasarwajo and Lasalimu Districts, and Muna language which is used in Lasalimu district. Nowdays, Buton has developed in several regencies, so CL also spread or found in several regencies. CL is spoken in Buton and South Buton regencies, Baubau Town, and Binongko and Togo Binongko Districts in Wakatobi Regency.

Ciacia language is grouped in Muna-Buton Language of West Austronesia Family (Sugono, at. All (ed), 2008). Phonologically, CL is vocalist language. Morphologically, CL has morphemic process, mainly affixation. It has several affixes, either prefix, infix, sufix, or circumfix. Based on grouping of language from Mallinson and Blake (1981) and Comrie (1983), $\mathrm{CL}$ is a language with algutinative type. Besides, based on constituent word order like what is done by Greembarg in Mallinson and Blake (1981), CL has SVO type.

Basically, there are several studies of CL. However, the results of those studies are limited, either in qualitative aspect, various theories used, language aspects, or mainly in syntactic typology study. This study investigated verbal clause of CL based on syntactic typology.

Specifically, the objectives of this study are: finding out and explaining verbal clause base construction of CL; (2) finding out and explaining predication construction and argument structure in verbal clause of CL; (3) finding out and explaining simple and complex predicate 
construction in verbal clause of CL; (4) finding out and explaining valency and valency change system in verbal clause construction of CL; and (5) finding out and explaining complex sentence construction and grammatical alliance system of CL.

\section{Theoretical Framework}

The theory which is used to investigate verbal clause construction typologically is come from Dixon (1994, 2010), Comrie (1981, 1983), Greembarg in Malinson and Blake (1981), Malinson and Blake (1981), Payne (2002), Song (2001), Artawa (2015), and Artawa and Jufrizal (2017).

Typology study etymologically means classificasion of domain. Typology technically refers to language groups based on the characteristics of word and sentence structures (Mallinson and Blake, 1981:3; Artawa, 2015:19). Languages can be grouped based on its structure characteristics. The languages which have similar characteristics will be presented in the same group. Every component in a language can act as a type or sign. A component that behaves as type constitues the object with permanent continuous and repeated forms in a language.

Comrie (1983) states that the purpose of linguistic typology is to group language based on its structure characteristic and acts. The main objective of typology study is to answer the question: what does the language like? Specifically, the objectives of typology study are (i) to group language based on its structure characteristic, (ii) to investigate the language differences, and (iii) to learn/investigate variations of human language. Otherwise, Dixon (1994, 2010) developed a system to describe grammatical issues in cross languages. It is called as pretheoretical syntactic primitives.

$\mathrm{S} \quad$ intransitive clause subject

A transitive clause subject

O intransitive clause object

$\mathrm{S}, \mathrm{A}$, and $\mathrm{O}$ are universal main category. Based on the system, A and $\mathrm{S}$ are grouped as subject. Therefore, every effort to make pure universal typology should be done based on the semantic principles. Subject is behaved as semantic category, namely subject is AGENT if the subject will be viewed in universal way (Artawa, 2015).

Valency in linguistics relates to verb as Pred. Valency refers to verb ability or need that take place in Pred component position following the argument. In grammatical process, valency 
also relates to increasing and decreasing of arguments. Increasing argument may occur through causativication and application (resultative). Decreasing argument may occur through pasivation, antipasivation, and intransitivation. Dixon (2010:165-167) states that derivation can change construction of a verb, from intransitive to transitive or from transitive to intransitive. Therefore, there are ways to investigate valency change, namely through (1) detransitivication and (2) transitivication.

Further, Alsina (1992:520) states that argument structure has semantic information about lexicon items which are relevant to syntax. Semantic structure and argument structure has correspondence with syntactic structure. The combination of both affects syntactic expression about argument. Syntactic change in causative sentence relates to semantic difference because semantic/argument structure difference has correspondence with different syntactic structure.

\section{Research Method}

This study arranges the systematic and accurate description of data, characteristics, investigated language phenomena relation with concern of verbal clause construction of CL based on typology point of view. Description of data which is based on pure language reality (not prescriptive way) shows that this study is qualitative-explanatory description. It is also field study because the natural data is obtained from in the field directly (Hyman, 2001:15-16). The data is obtained in the study field through source of several informants.

The study used written and oral data. Oral data is obtained from native speakers of CL in the field based on decided crteria. Written data is obtained from previous studies of CL. Besides, the researcher also has several own data (researcher is a native speaker of CL) with various variations and then are verified to the informants to find out the receptable and natural data.

In the data collection, this study used interview method with recording, note toking, and ellicitation techniques (Mithun, 2001). It was analyzed by using distributional and match methods with change and loss techniques (Djajasudarma, 2010:69; Sudaryanto, 1993; 2015:3747). The analyzed data was presented in study result raport in the forms of formal and informal methods (Sudaryanto, 1993; 2015:145; Mahsun, 2013:123).

To make this paper well understood, several abbreviations or terms used in the discussion section were presented first, as follows: $\mathrm{CL}=$ Ciacia language ACT $=$ Actor; $\mathrm{A}=$ Agent; $\mathrm{BEN}$ = Benefactive; UND = Undergoer; $\mathrm{S}=$ Subject $; \mathrm{O}=$ Object $;$ OBL = Oblique; Pred = Predicate; 
$\mathrm{GM}=$ Gender Marker; S/AM = Subject/Aspect Marker; PREF = Prefix; PN = Personal Name; $\mathrm{CAU}=$ Causative; $\mathrm{APL}=$ Aplicative $; \mathrm{PL}=$ Plural $; \mathrm{SG}=$ Singular; $\mathrm{PrO}=$ primary Object $; \mathrm{SkO}=$ secondary Object; COMP = Complement; $\mathrm{ARG}=$ Argument and NP = Nominal Phrase

\section{DISCUSSION}

The discussion covers (1) the verbal clause construction base of CL, (2) argument structure and verbal valency, (3) predicate and valency change system of CL, dan (4) active-passive construction/diathesis.

\subsection{Verbal Clause Construction Base of $C L$}

Discussion of verbal clause base construction is preceded by an explanation of free and bound personal pronoun (PP) and clitic of CL. PP of CL can existed in the free and bound forms, either in S/AM or clitic form. PP is always affixed in verb or verbalized as Pred. The presence of S/AM in verb as the criteria of acceptance of verbal clause construction of CL.

Verbal clause base construction of CL is filled by several syntactic relation, either S, O, or OBL with their semantic roles. One of the ways to determine grammatical relation of $\mathrm{S}$ in $\mathrm{CL}$ is through the marker form that is affixed on PRED verb in the form of S/AM. Subject relation can be known based on the S/AM form which is affixed to Pred verb. Other way to determine SUBJ relation in CL is thorugh a pivot test of omission NP on the second clause in the coordinative construction. While, determination of OBJ relation in CL is through pasivation. OBJ in active construction can place SUBJ position in passive construction by using passive marker $\{-\mathrm{e}\}$ and clitic passive PP form. Verbal clause base construction in CL can be classified on verbal clauses: (i) intransitive that is formed by intransitive base verb and non verbal category (verbalization); (ii) Semi-transitive which is filled by PRED verb and formed by semi-transitive base verb or other categories with affix $\{$ pi- $\}$; (iii) mono-transitive with PRED verb which is formed by both verb and non verb categories; (iv) ditransitive that is formed by monotransitive base verb and intransitive base verb or non verb category (verbalization) with affix BEN \{-aso $\}$; (v) ambitransitive that has two kinds, namely Sa type and So type. Based on word order pattern, verbal clause construction of CL can be classified in (1) word order pattern $\mathrm{S}+\mathrm{V}$ or $\mathrm{S}+(\mathrm{S} / \mathrm{AM}+\mathrm{V})$ with the change $\mathrm{V}+\mathrm{S}$ or $(\mathrm{S} / \mathrm{AM}+\mathrm{V})+\mathrm{S}$ or semantically in the forms of $\mathrm{A}+\mathrm{V}$ and $\mathrm{O}+\mathrm{V}$ or $\mathrm{V}+\mathrm{A}$ and $\mathrm{V}+\mathrm{O}$; (2) word order pattern $\mathrm{S}+\mathrm{V}+\mathrm{O}$ or $\mathrm{S}+(\mathrm{S} / \mathrm{AM}+\mathrm{V})+\mathrm{O}$ and semantically is $\mathrm{A}+$ $(\mathrm{S} / \mathrm{AM}+\mathrm{V})+\mathrm{O}$ with integral pattern (a) canonic passive form: $\mathrm{S}+(\mathrm{PS} / \mathrm{A}+\mathrm{V}+\mathrm{e}) \pm \mathrm{COMP}$ or $\mathrm{O}+$ 
$(\mathrm{S} / \mathrm{AM}+\mathrm{V}+\mathrm{e}) \pm \mathrm{A}$ and $(\mathrm{b})$ actor fronting passive form: $\mathrm{SUBJ}+\mathrm{COMP}+(\mathrm{S} / \mathrm{AM}+\mathrm{V}+\mathrm{e})$ or $\mathrm{O}+\mathrm{A}$ $+(\mathrm{S} / \mathrm{AM}+\mathrm{V}+\mathrm{e}) ;(3)$ word order pattern $\mathrm{S}+\mathrm{V}+\mathrm{PrO}+\mathrm{ScO}$ or $\mathrm{S}+(\mathrm{S} / \mathrm{AM}+\mathrm{V}+\mathrm{aso})+\mathrm{PrO}+\mathrm{ScO}$ and semantically is $\mathrm{A}+(\mathrm{S} / \mathrm{AM}+\mathrm{V}+\mathrm{aso})+\mathrm{BEN}+\mathrm{THEMA}$ and integral pattern is (a) diathesis objective construction (DOb): $\mathrm{S}+(\mathrm{S} / \mathrm{AM}+\mathrm{V}+\mathrm{isi}+\mathrm{e}) \pm \mathrm{COMP}+\mathrm{DO}$ or $\mathrm{BEN}+(\mathrm{S} / \mathrm{AM}+\mathrm{V}+\mathrm{isi}+$ e) $\pm \mathrm{A}+\mathrm{THEMA}$, (b) topicalization/focusing of agent (PAg) form: $\mathrm{S}+\mathrm{COMP}+(\mathrm{S} / \mathrm{AM}+\mathrm{V}+$ isi+e $) \pm \mathrm{DO}$ or $\mathrm{BEN}+\mathrm{A}+(\mathrm{S} / \mathrm{AM}+\mathrm{V}+\mathrm{isi}+\mathrm{e})+\mathrm{PrO}$.

\subsection{Argument Structure and Verbal Valency}

Argument structure and verb valency in verbal clause construction of CL can be classified to verbal predicate argument structure as follows: (1) intransitive with one main argument before verb or verb with one valency and act as A or as O; (2) mono-transitive with one main argument before verb and act as A and with the presence of one argument before predicate is obligatory and act as $\mathrm{O}$ or verb with two valencies; (3) ditransitive with one main arguments before predicate and act as A and the presence of two arguments after predicate is obligatory as PrO/BEN and ScO/THEMA or verb with three valencies; (4) semi-transitive that has one argument only before predicate or verb with one valency and act as A and the presence of other argument is optional; and (5) ambi-transitive construction on base construction has one main argument as $\mathrm{S} / \mathrm{O}$ before predicate and change to one argument as $\mathrm{A}$ before predicate and other argument as $\mathrm{O}$ after predicate in integral construction.

\subsection{Predicate and Valency Change System of CL}

Discussion of predicate in verbal clause of CL focuses on simple and complex predicate. Those aspects concerns to valency change system in verbal clause of CL. Predicate in verbal clause construction of CL is filled by (1) simple predicate that is formed from (i) intransitive base/source verb and non verb category, (ii) semi-transitive verb, and (iii) transitive verb. Those verbs are always cohered by S/AM. Besides it is filled by base verb, simple predicate can be filled by integral verb that is formed through intransitive and transitive base verb with several affixes. (2) Complex predicate is filled by (i) intransitive base verb with affix $\{$ po- $\}$, $\{$-wisi/ciwi $\},\{-$ pi/-wi $\},\{$ pi-...-wisi $\},\{$ po-...-aso $\}$, and $\{$ piko-...-aso $\}$, (ii) base adjective with affix \{piko- $\}$ and $\{$ piko-...-aso $\}$, (iii) transitive and intransitive base verb with affix $\{$-aso/-asopo $\}$, 
(iv) transitive base verb with affix $\{$ pi-...-aso $\}$, (v) lexicon pangulu 'first', pacimbughi 'after', and piwau 'made' with various word categories.

Valency change system in verbal clause construction of CL can be done through formal causativation and semantic causativation, applicative, and resultative. In formal causativation, CL has causativations of (1) lexicon, (2) morphemic, and (3) analytic.

Formal causativation lexically in CL commonly filled by transitive base verb-CAU as Pred with two arguments, namely argument $S$ as the causer and argument $O$ as causee that is stated by verb Pred-CAU. Morphemics causativation is done through affixes, either prefix, sufix, or circumfix. Thoses affixes are attached to intransitive base verb, base adjective, base noun, and transitive, and it then forms (i) verb of mono-CAU, (ii) ditranstive-CAU-BEN, and (iii) monoCAU and ditransitive-CAU-BEN. In analytic causativation, CL also needs affix, such as confix \{piko-\} 'made' that is attached to base adjective and prefix \{po-/pa-\} 'ask/give' that is attached to intransitive base verb. Besides, analytic causativation through hulanomo conjunction occurs in compound clause construction. The first one is free clause and act as causee, and the second one is bound clause and act as causer.

In semantic causativation, CL has pure and permissive causativations, and direct and indirect causativations. Semantic causativation in CL is also done through using several affixes CAU that are attached to intransitive base verb (non-causative) or through base verb CAU, while permissive causativation can be done through sufix $\{$-aso $\}$ that is attached to non-causative verb tadha 'let', so it forms the integral verb CAU tadhaaso 'let'. Direct causativation in CL is stated with affix CAU/BEN \{pika-...-aso\} that is attached to intransitive base verb (noncausative), and indirect causativation is formed from transitive base verb (CAU) and intransitive base verb with affix CAU.

In applicative process, CL has several affixes that are attached to intransitive base verb and transitive base verb. Those affixes that are attached to intransitive base verb form verb construction CAU-APL, affixes that are attached to transitive base verb form CAU-APL-COM. Besides, applicative in CL can be done through seried verbs, either with affix or S/AM only.

Decreasing of argument or valency in verbal clause construction of CL can be done through passivation and resultative. In passivation process, CL has several ways of decreasing valency or argument, as in the passivation in general. Through resultative, CL also has several 
ways of decreasing argument or valency, namely (i) S argument in integral construction is still kept on its position, (ii) passive marker $\{-\mathrm{e}\}$ is omissed (iii) Pred verb is attached by resultative marker $\{$ ci- $\}$ and its variation and it still keep S/AM, (iv) there is no A argument in resultative construction. Besides, in resultative and passivation, CL also has several affixes that are always touched on verb CAU and it then form intransitive construction, so it creates the decreasing of valency or argument. Those affixes like resultative forms and it is always formed by using affix $\{\mathrm{ci}-\}$ and combined together with other affixes. As a result, there is no A/ACT argument, but only $\mathrm{S}$ argument as $\mathrm{O}$, and it has passive and anti-causative meanings.

\section{Novelties}

Based on the test of two clauses in coordinative compound sentence construction, omission of nominal phrase on the second clause can be done directly without derivation process or without change of syntactic structure on either one of clauses or two combined clauses. CL has S/AM that is always affixed on verb or as Pred in sentence/clause construction of CL. The lossing of NP can be done directly without or with pasivization process. Although NP (lexically) as ARG A or ARG $\mathrm{S}$ on second clause that correspondence with ARG $\mathrm{S}$ on first clause or vice versa, in which it is not present or omissed, morphosyntactically it is changed by S/AM. CL is grouped as a language which has pivot system of S/A. The determination of this pivot system can be seen through lossing of NP on second clause which is done directly, without pasivation process. $\mathrm{CL}$ behaves $\mathrm{S}=\mathrm{A}$ and differs to $\mathrm{O} / \mathrm{P}(\mathrm{S}=\mathrm{A} \neq \mathrm{O} / \mathrm{P})$. Therefore, grammatical alliance system of CL can be presented as follow.

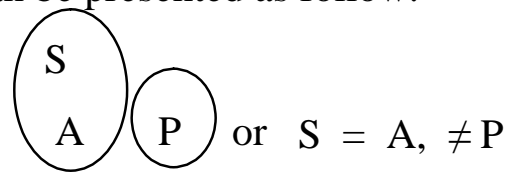

Grammatical alliance system of CL as verbal clause construction typology is supported by several grammatical evidences that $\mathrm{CL}$ is acussative language.

(1) Subject is always put before verb-Pred and has semantic role as agent (A).

(2) CL has subject and aspect markers and it is always affixed to the verb-Pred.

(3) CL has constituent order pattern: $\mathrm{S}+\mathrm{V}$ or $\mathrm{S}+\mathrm{V}+\mathrm{O}$. 
(4) In valency change system that involves (a) CL causativication shows as accusative language; (b) in applicativication, CL has object creating/fronting process; and (c) passivation process in active-passive diathesis.

(5) Syntactically, CL works with S/A pivot.

(6) Syntactically, CL behaves argument S and A in the same way, and behaves argument A and $\mathrm{O} / \mathrm{P}$ in different way.

Apart from that, this study found that CL has agentive diathesis as the underlying construction and objective diathesis and topicalization/focusing as the derived construction..

\section{Closing}

Based on the result of this study, some conclusions can be drawn as follows. Verbal clause construction of Ciacia language is always filled by subject and aspect markers (S/AM) that is affixed to Pred verb. The Base structure of verbal clause in CL consists of verbal predicated clause and non-verbal predicated clause. Non-verbal predicated clause can be constructed through base nominal and adjective categories. Verbal clause predicate can be filled by intransitive base verb, mono transitive base verb, ditransitive base verb, and ambitransitive base verb. Those verbal clause construction of Ciacia language always uses S/AM, either with affix or without affix.

Predication and argument structure of verbal clause construction in CL can be classified to verbal clause: (i) intransitive with one main argument in terms of $\mathrm{S}$ and as $\mathrm{A}$ or $\mathrm{O}$ systematically; (ii) semi-transitive with one main argument as $\mathrm{A}$ and with the presence of $\mathrm{O}$ argument optionally; (iii) mono-transitive with two main arguments, namely $\mathrm{S}$ as $\mathrm{A}$ with one $\mathrm{O}$ argument as UND, (iv) ditransitive with three main arguments, namely $\mathrm{S}$ as $\mathrm{A}$ before Pred and two arguments after Pred, in terms of PrO (primary object) and ScO (secondary object); and (v) ambi-transitive with one main argument, namely S, either as Sa or as So.

Valency and verb transitivity of verbal clause construction in CL consists of (i) valency and intransitive verba transitivity with one argument or verb with one valency; (ii) semitransitive verb with one argument before verb and the presence of argument after Pred verb optionally; (iii) transitive with the obligatory of $\mathrm{O}$ presence after Pred verb, so it has two main arguments or verb that has two valency arguments, namely S and O; (iv) ditransitive with three 
main arguments or verb that has three valency arguments, namely $\mathrm{S}$ before Pred verb, and indirect and direct objects after Pred verb; (v) ambi-transitive with only one argument or verb that has one valency, namely $\mathrm{S}$ as $\mathrm{O}$ (intransitive verbal clause) that coreference to other constructions, namely transitive verbal clause with two main arguments or verb that has two valency arguments.

Verbal clause construction in CL can be filled by simple Pred verb and complex Pred verb. Simple predicate is created by base verb/intransitive verb and non-verb category, semitransitive verb, and transitive verb with S/AM. Complex predicate is created through verb (i) intransitive integral that is formed by transitive and intransitive base verb with several affixes. (ii) semi-transitive verb that is formed by semi-transitive base verb and several affixes. (iii) transitive integral verb that is formed by transitive and intransitive base verb.

The valency change mechanism of verbal clause construction in CL can be done through formal causativation and semantic causativation, applicative, and resultative. In formal causativation, CL has causativation of (1) lexical, (2) morphemic, and (3) analytic. CL has several affixes that function in morphemic causativation process, either through prefix, double prefix, suffix, or circumfix to base verb (intransitive-transitive), base nominal, and base adjective. In analytic causativation, CL needs the presence of several affixes, like double prefix \{piko-\} 'made', prefix \{po-/pa-\} 'order/give' and causativation through conjunction hulanomo 'because' in coordinative construction. In semantic causativation, CL has pure and permitive causativations, and direct and indirect causativation. Pure causativation in CL is shown through intransitive verb or other non-causative categories.

Through applicative process, CL has several affixes, like suffixes that are used in the applicative process. Those affixes are used in the intransitive base verb (non-causative). Affix that is used on non verbal category only found on suffix $\{$-aso $\}$. Through decreasing process of argument or valency in CL can be done by passive and resultative process. In passive process, CL has passive marker $\{-\mathrm{e} /$-isie $\}$. In resultative process, $\mathrm{CL}$ has resultative marker $\{$ ci- $\}$ and keep S/AM, and it does not has argument A.

Based on the discussion and analysis of clause investigation in coordinative construction can be stated that $\mathrm{CL}$ syntactically behaves $\mathrm{S}$ similar to A, and different to $O / P(S=A \neq O / P)$. CL 
can be classified as a language with pivot S/A. The grammatical alliance system shows that CL syntactically tend to be a language with nominative-accusative typology.

\section{Acknowledgement}

The authors would like to thank to the Faculty of Culture Science of Halu Oleo University and Doctoral Program of Linguistics of Udayana University for giving permission and help in this project, and all who contributed so much of their time and ideas, especially to Prof. Dr. Ketut Artawa, M.A. as a supervisor, Dr. Made Sri Satyawati, S.S., M.Hum. as cosupervisor I, and Drs. I Nyoman Udayana, M.Litt., Ph.D. as co-supervisor II, and also the board of examiners: Prof. Dr. Aron Meko Mbete, Prof. Dr. Nyoman Kardana, M.Hum., Dr. Ni Made Dhanawaty, M.S., Dr. Anak Agung Putu Putra, M.Hum., and Dr. Ni Luh Ketut Mas Indrawaty, Dip.TEFL.,M.A. for their critical comments and suggestions for the improvement of this paper. Remaining errors are all mine.

\section{References}

Alsina, Alex. 1992. “On The Argument Structure of Causatives”. Linguistic Inquiry, Volume 23 Number 4 Halaman 517-555. Massahusetts Institute of Technology.

Artawa, Ketut and Jufrizal. 2018. Linguistik Tipologi. Denpasar:Universitas Udayana.

Artawa, Ketut. 2000. “Alternasi Diatesis pada Beberapa Bahasa Nusantara”:Dalam Kajian Serba Linguistik untuk Anton M. Moeliono, ed. Bambang Kaswanti Purwo). Jakarta:Universitas Katolik Atma Jaya dan PT BPK Gunung Mulia

Comrie, Bernad. 1983, 1989. Language Universals and Linguistic Typologys. Oxford:Basil Blackwell Publishid Limited.

Djajasudarma, T. Fatimah. 2010. Metode Linguistik Ancangan Metode Penelitian dan Kajian. Bandung:Refika Aditama.

Dixon, R.M.W. 1994. Ergativity. Camridge University Press.

Dixon, R.M.W. 2010. Basic Linguistic Theory Volume 1 Methodology. Oxford University Press.

Dixon, R.M.W. 2010. Basic Linguistic Theory Volume 2 Grammatical Topics. Oxford University Press

Dixon, R.M.W. 2012. Basic Linguistic Theory Volume 3 Further Grammatical Topics. Oxford University Press. 
Mahsun. 2013. Metode Penelitian Bahasa. Tahapan Strategi, Mtode, dan Tekniknya (edisi revisi).Depok.Rajawali Press.

Mallinson, Graham and Barry J. Blake. 1981. Language Typology. Cross Linguistic Studies on Syntax. Amsterdam:Nort-Holand.

Mithun, Marrianne. 2001. "Who Shapes The Record:The Speaker and The Linguist", In Newman, Paul and Martha Ratliff (ed). Linguistic Fiedlwork. Cambridge:Cambridge University Press.

Payne, Thomas. 2002. Describing Morphosyntax:A Giude for Field Linguistics. Cambridge:Cambridge University Press.

Song, Jae Jung (ed). 2001. Linguistic Typology:Morphology and Syntax. Harlow:Longman.

Sudaryanto. 1993, 2015. Metode dan Aneka Teknik Analisis Bahasa, Yokyakarta:Gajah Mada University Press.

Van Valin, Robert., Jr and Wiliam A Foley. 1980. "Role and Rference Grammar" dalam Moravesik and Wirth. Editos

Van Valin, Robert., Jr dan Randy J. La Polla. 1997. Syntax:Structure Meaning and Function. Cambridge:Cambridge University Press. 


\section{Biography of Author \\ Biography}

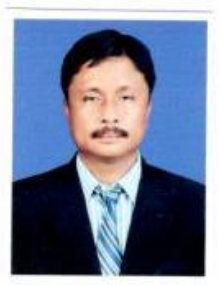

La Yani, a lecturer at Halu Oleo University, was born in Buton, Southeast Sulawesi, Indonesia, $19^{\text {th }}$ of April 1967. He completed the bachelor program (S1) on language and letters education Department of Halu Oleo University on July 1991, and his magister program (S2) on Linguistics Concentration of Letters Sciences was graduated in Postgraduate Program of Padjadjaran University on February 1999. In 2014, he joined to doctoral program (S3) of Linguistics Department in Udayana University, and the title of his dissertation is "Verbal Clause Construction of Ciacia Language:Syntactical Typology Study. He has taught several subjects of linguistics since he has been a lecturer in Halu Oleo university. There are several researches that have been done, like Word Category Analysis of Ciacia Language, Morphology Structure of Ciacia Language, and Syntactics Structure of Ciacia Language. The result of these studies is not only published in Journals but also in Proceedings. It Several results were published in Uvula (Bandung), Semiotika (Kendari), Linguistika (Udayana-Bali), Lingual: Journal of Language and Culture (Udayana-Bali), International Journal of Linguistic, Literature and Culture. Besides, the result of these studies were published in proceedings, either national or international proceedings, like Proceeding The 7th Inter Sem Austronesian, Bali; Proceeding Inter Conf Linguistic , Bandung; and Proceeding Conferance On L3, Singapura. 